\title{
A Reassessment of the Decline of the Khmer Empire
}

\author{
Lawrence G. Gundersen, Member, IEDRC
}

\begin{abstract}
This research surveys and adds to the numerous modern reasons given for the decline of the Khmer Empire after Jayavarman VII. The work highlights new evidence indicating that severe climate change directly affected the Khmer Empire after 1200, and examines how the biological factors and impact of disease related to this climate change would have been critical in undermining and degrading the Khmer population. Using primary sources and inferential evidence on disease, the intent of the study is to build on the established and generally accepted assumptions for the collapse of the Khmer Empire, including to explain that localized, severe, and long-term climate fluctuations were a problem for the Khmer, and, most importantly, to show that climate change, as it encouraged and was related to epidemics and diseases, is what significantly attrited the Angkorian population.
\end{abstract}

Index Terms - Climate change, disease, environment, Jayavarman VII, Khmer Empire.

\section{INTRODUCTION}

The question of what ultimately led to the downfall of the Khmer Empire after Jayavarman VII has perplexed modern historians, archeologists, and anthropologists for years. For many, the finger often points to either Jayavarman VII for overbuilding the empire or to weak, succeeding emperors for their inability to maintain the empire. New evidence, climate change data, opens up other possibilities for the decline of the Khmer Empire. Most historians would agree that there was no one definitive cause for the collapse, but insuring that all of the available records and possibilities are explored will help to develop a more accurate and complete narrative of the empire's decline.

Lawrence Briggs, author of "The Ancient Khmer Empire" (1951), identified what he thought were the reasons for the demise of the Angkor civilization in Cambodia's history: a construction frenzy, loss of revenue, loss of labor, conversion to Hinayana Buddhism, and the sack of Angkor by the Thai (Siamese) in 1430-1431 [1]. Bernard-Philippe Groslier further theorized that the collapse of Angkor's water management baray system, from siltation, flooding, and erosion, contributed to the downfall. The Greater Angkor Project, which includes Khmer archaeologists Roland Fletcher and Damien Evans, has proven that the hydraulic system of Angkor, the "strategic asset" of the empire, ultimately failed [2]. There are additional reasons for Angkor's collapse [3], and one closely related to the hydraulic cities has been recently identified and developed: climate change. In 2010, some scholars identified climate change as a factor in the eventual end of the Khmer Empire [4], and this

Manuscript received February 19, 2015; revised May 25, 2015.

Lawrence G. Gundersen is with the Univ. of Tennessee, Martin/Jackson State Community College, USA (e-mail: lggundersen@ hotmail.com). was followed up in 2012, with a more definitive study of the impact of climate change in Southeast Asia during the Angkor era of the Khmer Empire [5].

Many factors brought the once great Khmer Empire to its collapse, but the environmental issue of climate change would have caused eco-biological issues critical in undermining and degrading the population of this civilization. With the environmental impact of long-term cycles of drought and flooding established [4], [5], biological factors and disease, such as the Black Death, need to be reconsidered. The intent of this study is to convey that localized, severe, and long-term climate fluctuations wreaked havoc on the population centers of the Khmer with epidemics and diseases, thus greatly weakening the population and the civilization.

\section{Climate Change During THE KHMER EMPIRE}

The tree rings from the Dangrek Plateau and the Central Highlands and the stalagmite records from the Dandak Cave in India show some remarkable climate and parallel trends associated with the Medieval Climate Anomaly (MCA) transition to the Little Ice Age (LIA) in Southeast Asia [4], [5], but specific paleoclimate data on specific locales is non-existent. What we do know is that there was higher rainfall associated with the MCA from around 900/950 until 1250/1300, which provided for the rapid growth of Khmer agriculture and population [5]. From the late 1200s to the mid-1400s, specifically between 1290 and 1340, Cambodia was much drier [5]-[7], thus indicating the onset of the LIA. Converging data with the tree ring and stalagmite analysis should be obtained, as one scholar suggested, from taking multi-location sediment cores from the Tonle Sap and reconstructing the geo-environmental and biological changes [8].

The cause of the dramatic increase in precipitation cycles in the MCA were from frequent or sustained warm La Nina winds and currents that tend to enhance Southeast Asian, South Asian, and Southern China monsoons. If there was a 500 year repositioning of the Inter-tropical Convergence Zone (ICZ) southward, where winds from the southern and northern hemispheres intersect, from roughly 900 to 1300 , and the ICZ transitioned north during the change to the LIA [5], Angkor by the 1300s would have suffered prolonged and lethal droughts with water-intensive crops like rice. Solar radiation was strong from the tenth to late thirteenth centuries, the period of the MCA, but very weak during the Wolf Minimum period of radiation (1280-1340). In addition, volcanic activity reinforced the cooling impact of reduced radiation, and moderated the warming effects of radiation increases. From 1225 until 1233, from 1256 until 1262, and then again from 1444 until 1465, the hemispheric temperature had pronounced decreases associated with volcanic activity 
[5]. For much of the fourteenth century, persistent droughts from the El Nino Southern Oscillation northward would have limited or crippled Khmer rice and fish harvests.

The area around Siem Reap, near the northwest corner of Tonle Sap Lake, the heartland where the Angkor civilization thrived, is "a natural flood plain" [2], [9]. The Khmer emperors were fairly effective in channeling the Monsoon flooding with the baray (reservoirs surrounding Angkor Wat, Angkor Thom, Banteay Chhmar, and other sites) hydraulic system and with other channels to run the excess water back to the Tonle Sap or paddy [9], [10]. In fact, water transportation was a primary means of travel during the Khmer Empire especially during the Monsoon season. However, sedimentation and siltation of the canals and waterways around Angkor from clear cutting the hillsides north and northeast of Siem Reap have been identified as additional reasons for the eventual collapse of the baray system, thus Angkor [10], [11].

The recent study on historic climate change in Southeast Asia confirms that the Monsoon patterns were erratic and varied somewhat between the eastern and western parts of the region. The tree rings studied in Thailand and the Central Highlands of Vietnam showed these variations in rainfall, but they also showed significant parallel and sustained periods of growth and stunting. Most importantly, the study established decade long periods of drought or flooding during tumultuous years of Angkor and the whole of Southeast Asia [5]. One historian claimed that the great baray, which gave liquid life to the Khmer populations, of Angkor Wat and Angkor Thom were used for emergency irrigation [12]. However, the amount of water located in the baray, of the various geographically located Wat, would have only been used to sustain the population with vital drinking and cooking water during drought. Rice is a water-intensive crop. Decades long droughts would have further strained the existing baray just to meet drinking and cooking water needs. Given the new discovery that the surrounding urban area of Angkor is much larger than originally thought [13], and thus the population was much larger, it is difficult to see how there would have been surplus water from the baray for irrigation - let alone during a prolonged drought [12].

\section{DISEASE DURING THE KHMER EMPIRE}

Closely tied to the climate issues of drought and flood facing the Khmer was disease. The jungles of Southeast Asia represent a perfect biological incubator for some deadly toxins, poisons, and diseases. The diseases that impact humans and animals would have also taken a toll on the Khmer. Even today, in the area around Pailin, where the Khmer Rouge were decommissioned, the United Nations is trying to control and contain a virulent form of malaria that is drug-resistant [14].

Most past and present human infectious diseases originated with other animals: Influenza, plague, tuberculosis, malaria, HIV, Ebola, and SARS. And, in some cases, the ecological changes of sedentary life, animal domestication, and urbanization, may allow the entry of a pathogen into the human population. In some instances, a pathogen may cause only sporadic cases and clusters of cases and cannot sustain itself without repeated re-introduction. However, when a pathogen acquires specific evolutionary adaptations that allows for human to human transmission, or an evolutionary mutation from human to human, is when large-scale epidemics may occur [15].

Briggs mentioned disease as an issue impacting the Khmer of Angkor, but he did not identify it as a significant factor. Frank Fenner later dispelled the idea smallpox would have been a major contributing factor in the Angkorian demise because of the survivability rates in large populations and the shift from epidemic to endemic in a population [16]. However, Thai historic records indicate that the Thai, and probably the Khmer, sometime between 1330 and 1352, suffered a major smallpox epidemic "and much of the population succumbed to it" [17].

Most recently, Lieberman and Buckley cited the Fenner study in their climate work, but they seem to discount disease as a major factor in this civilization's collapse [5]. Damien Evans, with the Angkor Project, said "the topic required much more study [2], [9]." During droughts or heavy flooding, disease would have been rapidly transmitted, and diseases as tough, or tougher, than smallpox would further attrite the Angkor population. According to the Thai records, cholera, sometime between 1351 and 1369, had taken its toll on the royal family [17]. There should be no doubt that this same cholera wave struck the Khmer from the increased contact and fighting with the Thai after 1250 .

Lieberman and Buckley assure us that the survivability rates from a smallpox die-off would have been sustained by the "charter state" populations of Southeast Asia [5]. However, Willaim McNeill, in Plagues and Peoples, argues that the Mongol/Chinese contracted Pasteurella pestis from Burma in 1253 [18], which was on the borderlands of the Angkorian realm [10]. By 1331, bubonic plague began to ravage the population of China. It hit Europe by 1346 [18]. Although the Khmer, Thai, Champa, and Dai Viet probably suffered major human losses from plague epidemics, we do not have any surviving records to verify numbers of deaths [17]. However, we can look at what Chinese observers recorded during the first years of infection. According to one chronicler, nine out of ten people died from the plague in Hopei Province in 1331, and by 1354, three-quarters of the population died from plague. China was at war with the Mongols during some of that time, but the decrease in China's 1200 population of 123 million to 65 million by 1393 is profound [18], [19]. Something other than war caused the loss of half the population of China between 1200 and 1393 .

If half the population of China died between 1200 and 1393, then one fourth of the population probably perished under the yoke of Mongol control and one fourth of the population died from plague. This fits with the generally accepted death rates from the plague in Europe. Given this, we can assume that one fourth of the Angkorians died from plague.

Even if the Khmer population had achieved a suitable microparasitic accommodation to the ecological challenges in the Tonle Sap basin and Mekong River Delta and valley, and achieved a regulated macroparasitism with plague that allowed a natural population increase, as what happened with the Chinese over time, bilharzia, dengue, malaria, Guinea 
worm, leprosy, cholera, smallpox, and chikunjgunya, primarily tropical and vector-borne diseases, delivered repetitive blows to a population already struggling with long-term droughts by 1300 . The plague probably arrived in Angkor after 1250, when it looks as if the long term droughts were hitting, and it probably ran its course from epidemic to endemic within 100 years. There were no decisive disease manifestations during the Angkorian period of the Khmer Empire, but a steady degradation of the population after 1250 , from diseases and droughts, significantly weakened the population. There is inferential evidence that disease would have been prevalent.

The evidence of the ritual death funerary, of which the various Wat are dedicated, in part or in whole, were for the royals in this hierarchical society. Surely, these death ceremonies would have been grand affairs to witness. However, most Khmer, by tradition, did not cremate human remains in the Hindu fashion. The Ankgorians carried their dead outside of the population centers for wild dogs and birds to devour [1], [20]. Remains quickly devoured ensured a good reincarnation and afterlife (samara), and remains decaying slowly were a negative reflection on the family. This funeral ritual would have contributed to the spread of disease.

Human and animal waste, and the attending increase in phosphates in the baray system during drought or extended droughts, would have decreased the protein source of the Khmer. And, the human waste in the canals and waterways of the urban areas would have helped to transmit diseases, especially with starving populations. If Bernard-Philippe Groslier was correct, that there were 1.9 million people in the Angkor Wat and Thom metropolitan complexes, and it is increasingly likely he was correct with the results of the recent LiDAR imaging of the area [13], then the discussion of disease is critical in any narrative history of the Khmer Empire.

Lieberman and Buckley in their population estimation of Angkor cited an older study from 2003, which showed a population of 750,000 in the Angkor Wat and Thom areas [5]. The recent LiDAR survey shows a much larger metropolitan complex than the earlier studies were based on, and what was cited by Lieberman and Buckley in their work. Groslier was probably correct, that the population of the Angkor complex was 1.9 million, given what we know now about the actual size of this major urban complex. The question, for our purposes, becomes "How many Khmer died from diseases between the peak of Jayavarman VII's empire at the beginning of the thirteenth century until the end of the fourteenth century and Angkor's abandonment for Phnom Penh?"

This is a very difficult question to answer for one main reason: Lack of records and documents [10]. Although the French have done the heavy lifting with regards to archaeology, translations of Sanskrit, Pali, and Khmer, and documentation and interpretations of Khmer art and architecture, there are no written human/mortality records. The Chinese kept fairly accurate population and epidemic records; hence, we might glean some comparative estimates of what the plague did to the Angkorians. If, as I have suggested earlier, one fourth of the Ankgorians died from plague epidemics, and if repetitive diseases ravaged the
Khmer population, along with Angkor, the empire would have been a virtual hot zone for the transmission of diseases and re-introduction of diseases.

\section{Climate AND Disease DisPRUPTION OF THE KHMER EMPIRE}

The Khmer Empire, situated in what is roughly Cambodia today, was sustained by a series of warrior kings; some weak and some strong. The empire Jayavaraman VII built, with royal-operated and run transit shelter stations about every 15 kilometers, was dependent on human and animal portage. He built 102 hospitals, which indicates the needs of a sick population, and extended his dominion into Laos and Thailand. [1], [10]. Wheeled vehicles were not always conducive to the environmental conditions of Cambodia, and so water transportation was preferable in many instances. The logistical challenge in supplying, let alone further extending, the empire in this environment had limiting effects on its expansion, defensive capabilities, and offensive capabilities.

Cycles of massive death from epidemics are, even today, often associated with cycles of drought and flooding. Despite their ability to somewhat control flooding and droughts with reservoirs, channels, and irrigations systems in and around Angkor Wat, Angkor Thom, and other places like Banteay Chhmar, the Khmer's ability to maintain a robust and healthy population to serve the empire was compromised to the point where it was increasingly vulnerable from disease to external threats by the Cham, Dai Viet, and, most importantly, the Thai.

Furthermore, trade and food production within the Empire may have mitigated some food shortages brought on by drought in certain locales. The trade and commerce network centers developed under Jayavarman VII would have ensured prioritization in the distribution and transportation of scare resources. If the western part of Cambodia was in drought, the eastern part may not have been. From the Dangrek Range and Khorst Plateau of Thailand, to the Central Highlands and Mekong Delta of southern Vietnam, what is basically Cambodia today, and what Jayavarman VII at the beginning of the $13^{\text {th }}$ century could call his empire [1], there are different weather and weather patterns. For example, Cambodia recently suffered from flooding, but Takeo Province south of Phnom Penh was in a severe drought [21]. In the northwest (the Tonle Sap's floodplain), tubers dominate the agricultural production today because of questionable rain, inadequate catchment for rice, and lack of sheet and rill erosion control. The various different food production regions may have sustained the Khmer Empire in a drought, or in an advance on one region by the aforementioned existential threats, but could the Empire sustain decades of drought, disease, and/or flooding? Could it survive an enemy advance on one region while having a water shortage in the other region?

\section{CONCLUSION}

As the story about Angkor's collapse is increasingly complete, a stronger effort must be made to try to include the disease and biological factors that impacted Angkor in the 
narrative. I have only looked at the circumstantial, inferential, and available written evidence of disease during the Khmer Empire, as the written records are almost non-existent, but further work needs to be completed to identify the critical pathogens that did strike Angkor and its people. The sources for the incorporation of eco-environmental forces and climate change into the modern historical narrative are the natural and human archives. The natural archives of ice cores and glaciology, palynology, dendrochronology, and speleothems allow scientists and historians to "rewind the tape of history" from a scientific basis when the human archives of narratives, numerical information, pictorial representations of natural phenomena, epigraphic and inscription information, or instrumentation data are few, missing, or non-existent [22].

The problem in studying disease in Angkor is that there are no real human archives - save for a few inscriptions. Of the natural archives, studying the ice is not possible. Lieberman and Buckley graphed the available dendrochronology and speleothems, and that leaves palynology. As mentioned earlier, sediment cores from Tonle Sap and around Angkor would provide convergent data for climate studies, but the pollen and spores would shed light on the microbial world of Angkor.

What we do know is that on ten of the surviving hospital stele inscriptions attributed to Jayavarman VII (J7), in the $13^{\text {th }}$ stanza, are the words, "The bodily pain of men became in him (J7) a pain of the soul and was more painful to him (J7) than to the actual invalids, for it is the suffering of the State which makes the suffering of the kings and not their own pain [23], [24]." Here he acknowledges what had to be a vexing Khmer population problem, or why would he have mentioned it? The $14^{\text {th }}$ stanza, more of a follow up, which shows the authority of the deva raga, states, "With the help of the physicians, the warriors versed in the science of the arms of medicine, he (J7) destroyed the enemies of the kingdom - the maladies [25]." The "maladies" after Jayavarman's reign continued, and worsened for over 200 years, but given the scant human archives available only palynology can provide the final clues on the specific diseases that contributed to Angkor's collapse by the mid- $15^{\text {th }}$ century.

\section{REFERENCES}

[1] L. P. Briggs, "The ancient khmer empire," Transactions of the American Philosophical Society, New Series, vol. 41, no. 1, pp. 258-260, 1951

[2] R. Stone, "Divining angkor," National Geographic, pp. 32-35, pp. 48-51, p. 54, July 2009.

[3] V. Lieberman, "Maritime influences in Southeast Asia, c. 900-1300: Some further thoughts," Journal of Southeast Aisan Studies, vol. 41, no. 3, pp. 529-539, 2010.

[4] B. M. Buckley and A. Et, "Climate as a contributing factor in the demise of angkor, cambodia," in Proc. the National Academy of
Sciences of the United States of America, vol. 107, no. 15, pp. 6748-6752, 2010.

[5] B. M. Buckley and V. Lieberman, "The impact of climate on Southeast Asia, circa 950-1820: New findings," Modern Asian Studies, vol. 46, no. 5, pp. 1049-1096, 2012.

[6] A. Reid, "Expansion and crisis," Southeast Asia in the Age of Commerce, 1450-1680, vol. 2, New Haven: Yale Univ. Press, 1993.

[7] V. Lieberman, "Integration on the Mainland," Strange Parallels Southeast Asia in Global Context, c. 800-1830, vol. 1, Cambridge: Cambridge Univ. Press, 2003.

[8] S. Tsukawaki, "A geological approach to interpreting the Khmer civilization," Renaissance Culturelle du Cambodge, Paris, Sophie Univ. Press, 1995, pp. 1-2.

[9] A. Walsh and J. Drennon, "Lasers reveal angkor city four times bigger than previously believed," The Phnom Penh Post, 20 June 2013.

[10] C. Jacques and P. Lafond, The Khmer Empire: Cities and Sanctuaries from the 5th to the 13th Century, Bangkok: River Books, 2007.

[11] J. Sanday, "Saving banteay chhmar," World Archaeology, p. 52, 7 March 2007.

[12] C. Leytham-Powell, "Betrayal of natural resources: The fall of the angkor and mayan civilizations," Grand Rapids, 2012.

[13] N. Swaminathan, "Remapping the khmer empire," Archaeology, p. 29, Jannuary/February 2014.

[14] N. White, "Drug resistant malaria is a disaster, we have one chance to halt it," The Guardian, 31 July 2014.

[15] J. B. A. A. T. Day, "The effects of disease life history on the evolutionary emergence of novel pathogens," Biological Sciences, vol. 272, no. 1575, p. 1949, 2005.

[16] F. Fenner, "Smallpox in Southeast Asia," Crossroads, vol. 3, pp. 34-35, 1988.

[17] D. K. Wyatt, The Royal Chronicles of Ayutthaya, Bangkok: Siam Society, 2006.

[18] W. H. McNeill, Plagues and Peoples, Garden City: Anchor Press, 1976.

[19] J. D. Durand, "The population statistics of China, A.D. 2-1953," Population Studies, vol. 13, no. 2, pp. 228-248, 1980.

[20] C. Ta-Kuan, The Customs of Cambodia, Bangkok: Siam Society, 1992.

[21] D. de Carteret and C. Muyhong, "Takeo rice farmers pray for rain," The Phnom Penh Post, 23 August 2014.

[22] G. Parker, Global Crisis, New Haven: Yale Univ. Press, 2013.

[23] B. R. Chatterji, "Recent Advances in Kambuja Studies," Journal of the Greater India Society, vol. VII, no. 1, January 1940.

[24] R. C. Majumdar, Kambuja-Deas or an Ancient Hindu Colony in Cambodia, Chennai: Univ. of Madras Press, 1944.

[25] B. R. Chatterji, Indian Cultural Influence in Cambodia, $2^{\text {nd }}$ ed., Kolkata, West Bengal: University of Calcutta Press, 1964.

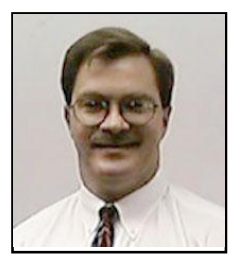

Lawrence G. Gundersen was born in Georgia, USA in 1959. He received his BS degree in history and political science, from University of West Alabama in 1988. He got MAT in history from University of West Alabama, in 1989. He obtained his $\mathrm{PhD}$ degree in history from University of Memphis in 2004. He is currently a professor of history and political science. His research interests include South and Southeast Asian environmental history and politics, women's history, agriculture history. 